\title{
A techno-economic study of shipping LNG to Indonesia from US, Australia, and Qatar by LNG carrier
}

\author{
M.J. Giranza ${ }^{1, a, *}$, A. F. Pratama ${ }^{2}$ and G. A. Hutomo ${ }^{3}$ \\ ${ }^{1}$ Centre of Energy, Petroleum, Mineral Law, and Policy University of Dundee, Dundee, United \\ Kingdom \\ ${ }^{2}$ College of Engineering Technology Universitas PLN, Jakarta, Indonesia \\ ${ }^{3}$ Commercial Analyst Pelindo Energi Logistik, Denpasar, Indonesia \\ a.mjgiranza@dundee.ac.uk \\ *corresponding author
}

Keywords: LNG, Natural Gas, LNG Carriers LNG, LNG Shipping, Indonesian LNG.

Abstract: With respect to the Indonesian natural gas supply and demand, the margin between combined supply and the next 15 years demand results to a negative supply after the year 2019. It is mandatory for the government to increase the supply either by importing natural gas from the other countries. From Indonesian location, there are a few countries which have abundant resources of natural gas in different locations as potential exporters. For this paper, we developed a model that estimates the cost of shipping one MMBTU of LNG on a per-voyage basis from three natural gas producer countries which are the US, Qatar, and Australia. The shipping cost of the project is calculated by summing up the port and passage fees, LNG carrier hire cost and fuel oil cost. This analysis demonstrates that shipping from Australia has the lowest cost with 0.43 USD / MMBtu. The shipping costs from Qatar and the US are 1.03 USD/MMBtu and 3.16 USD/MMBtu, respectively. Based on the analysis, the shipping cost is mostly influenced by the fuel cost compared to other costs. The pure-gas burning propulsion system is also feasible to be used. The cost-benefit of using boil-off gas generated rather than oil fuel as a primary fuel should be studied further to give more comprehensive analysis.

\section{Introduction}

According to the report published by Ministry of Energy and Mineral Resources, there will be a decline in natural gas supply and the total demand will exceed the total supply by 2019 [1]. In this case, it is mandatory for the government to meet the natural gas demand either by boosting the oil and gas exploration activity to discover new oil reserves or importing LNG product directly from other countries [2].

Since the oil discovery has a high uncertainty [3-6], the second solution seems more reasonable to do. The government is planning to import natural gas for the first time by 2019 from other countries [2]. Importing in the form of LNG is one the best choice because of the complicated geographical condition of Indonesia, which is separated with other countries by deep sea [7]. As shown in Figure 1, the Indonesian archipelago is located between two oceans, the Pacific and Indian, and consists of small islands which are stretched evenly in the eastern region [8]. Eastern 
region seabed ranges from 1,000 to 7,000 meters deep. Due to the fact that pipelines cannot be used to deliver the gas through the deep sea area for long distances, importing pipeline gas it is not relevant for this case [9-11].

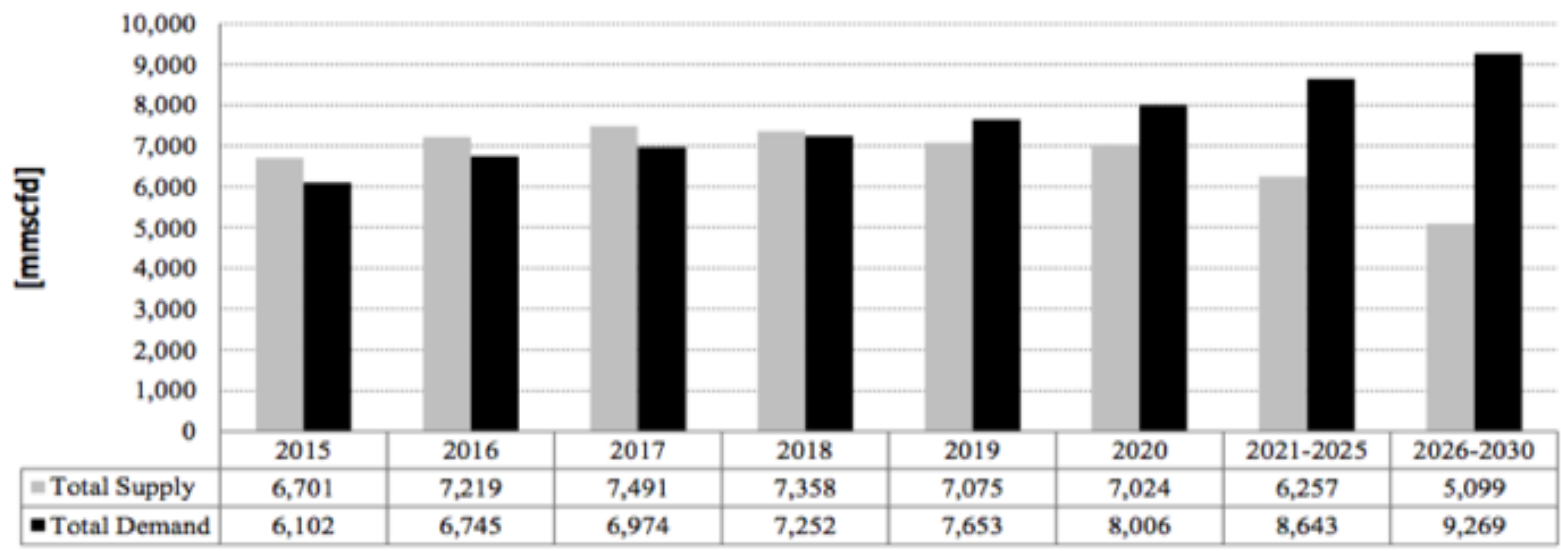

Figure 1: Indonesian Natural Gas Supply-Demand 2015-2030 [1].

This research aims to asses the scenarios of importing LNG from the potential exporter countries. The plan is also supported by the new regulation regarding the opening of the import faucet of LNG which was announced by the Indonesian government in 2017 [12].

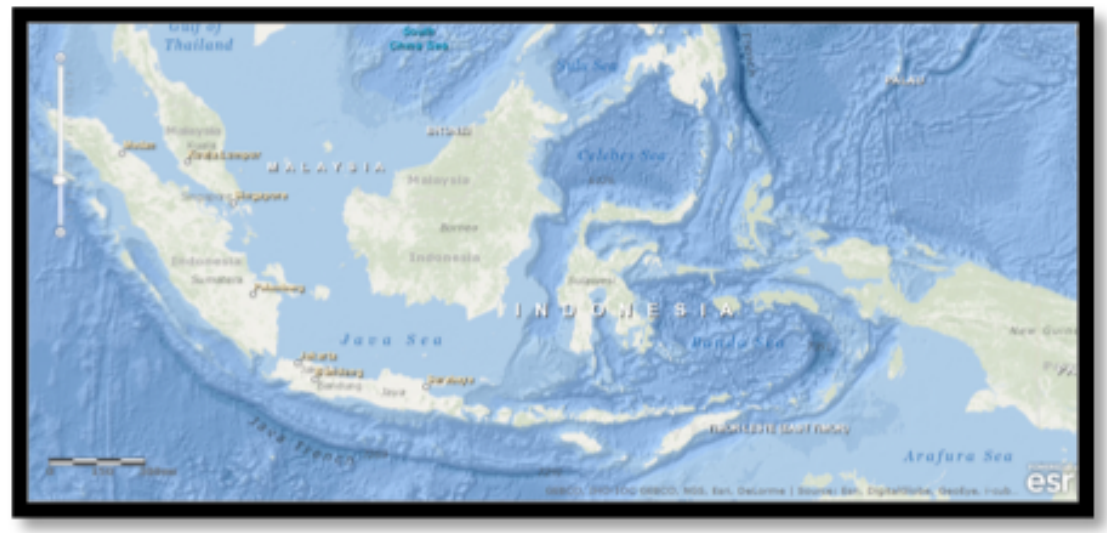

Figure 2: Map of Indonesia [8].

Although Indonesia is predicted to import LNG by 2019, journals published on this specific topic are not found. Comprehensive literatures of LNG shipping cost are available but discussing the general concept or using the other countries as the cases, not Indonesia [13-16]. There is a paper by [17] about Indonesia LNG shipping but Indonesia is set as an LNG exporter, not an importer.

This paper aims to fill the gap of the lack of study about the LNG import to Indonesia. This research is prepared to encourage the other scholars to do similar investigations to provide various scenarios of LNG import to Indonesia. Also, the explanation on this paper delivers a new perspective to the LNG producer countries to target Indonesia as the market. 


\section{Indonesian Natural Gas Market}

To open the access of importing gas and making the natural gas affordable for power generation, the Indonesian Government determined the price of domestic natural gas which is $14,5 \%$ of Indonesian Crude Prices (ICP) in the plant gate [12]. If the domestic natural gas price is higher than that rate, the government is allowed to import the LNG from the other countries. Previously, LNG import was not allowed to maximise the absorption of domestic gas, although the domestic gas price is more expensive than LNG import. The Indonesian Crude Price changes every month. For example, in November 2017, the ICP is USD 56.76/bbl. Therefore, the LNG price from overseas must be less than $14.5 \%$ of $56.76 \mathrm{USD} / \mathrm{bbl}$, which is $8.23 \mathrm{USD} / \mathrm{MMBTU}$, in the plant gate to compete with the domestic natural gas.

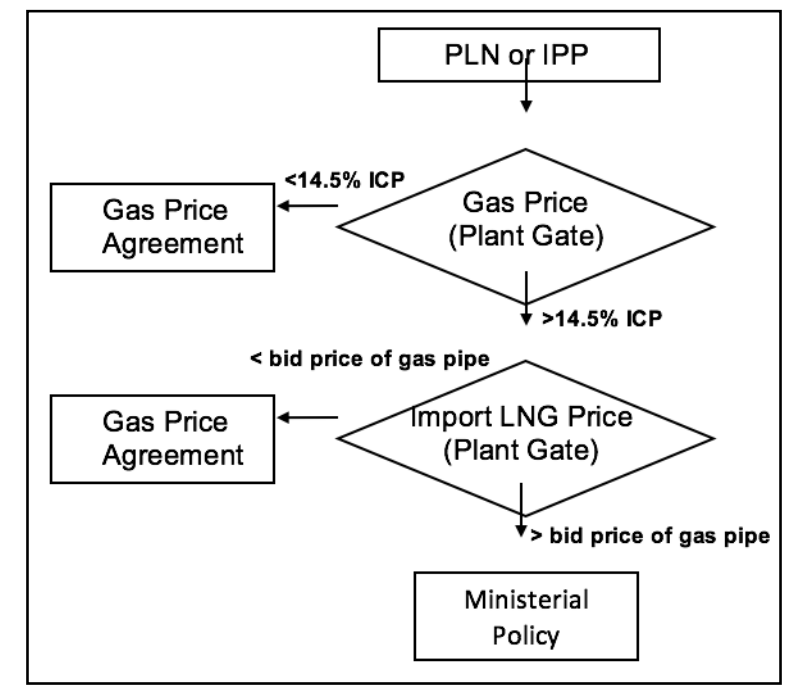

Figure 3: Scheme of Indonesian Gas Allocation.

\section{LNG Supply Chain}

LNG is the process of changing natural gas to liquid for the more efficient transportation [18]. LNG is a fast-growing method of monetising natural gas and is the cleanest- burning hydrocarbon [19-23]. The LNG value chain begins upstream with exploration and production and then moves on to the midstream with processing and transportation and then finally into the downstream where it is liquefied and then eventually regasified and distributed to consumers [10, 24]. 


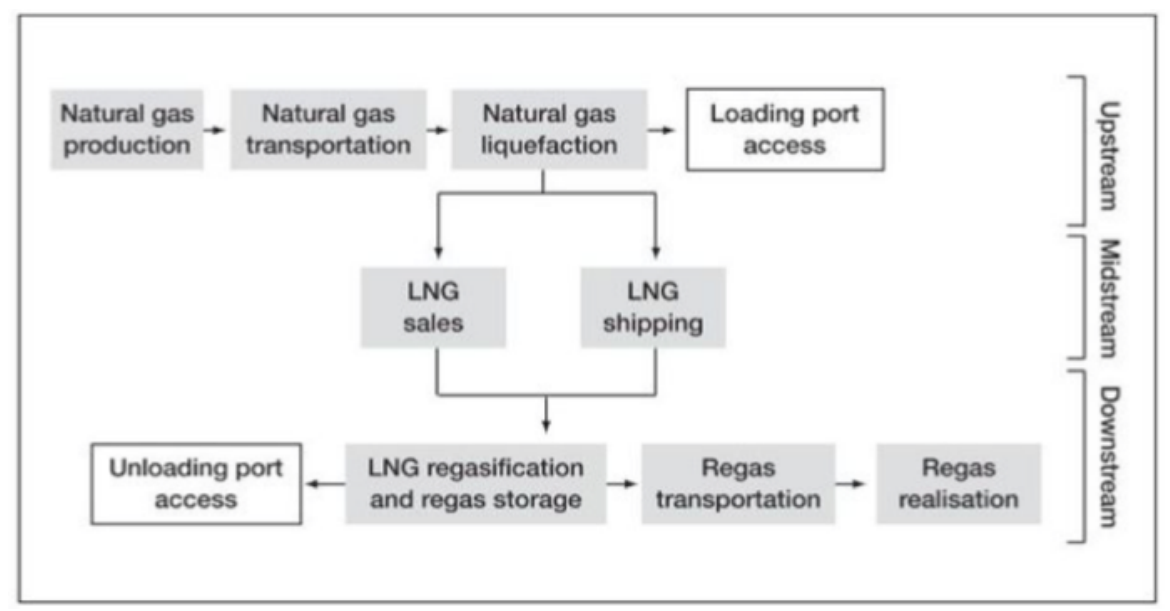

Figure 4: LNG Supply Chain

Source: The Law and Bussiness of LNG, Second Edition (2012).

LNG projects are capital intensive at every stage, and they are often front-end loaded meaning that revenues from the project do not accumulate until the project is complete [25]. The traditional LNG structure allows for long-term contracts usually 20-25 years which guarantees a sales volume and is sufficient for investment pay-back [24].

The process of making LNG is mainly cooling the natural gas to a temperature of $-162^{\circ} \mathrm{C}(-$ $260^{\circ} \mathrm{F}$ ) which makes it a liquid and then regasifying it before distribution $[10,26]$. he prospects for LNG are very high in the future, and global demand is said to grow at around 5\% annually. Global demand for LNG could increase to about 430 MPTA (million tonnes per annum) in 2025. For comparison, just 80,000 tonnes of LNG were shipped by two carriers in 1964, the first year of the LNG trade.

The company can acquire the LNG carrier in two ways: by purchasing and owning the vessel or chartering it under the time or voyage $[9,10]$. For simplicity, we assume that the company prefers chartering the vessel to owning it. Under a time charter, the vessel is hired for a specific period (e.g. 12 months), with the charterer paying a daily rate of hire for the vessel. The shipowner provides the vessel with the crew, stores and provisions, ready to load cargo and proceed on a voyage. The charterer pays for the expenditure directly resulting from compliance with its instructions, such as bunkers (fuel costs and a significant item), port charges and the costs of loading and discharging the cargo.

\section{Result \& Discusions}

\subsection{Fuel Consumption}

Fuel consumption is estimated using the logical structure described in section 3.1 and presented in Table I below. As the pure fuel-oil based system used in the first case, no boil-off gas is consumed for power. The boil-off gas generated is re-liquefied to make the total energy of LNG remains stable until reaching the port of destination. Figure 8 shows the total voyage fuel consumption for all three exporting countries considered. From all three scenarios, it is evident that the fuel consumption from the US is the highest one due to the greater number of sailing days compared to Australia and Qatar. 
Table 1: Fuel Oil Consumption Calculation

\begin{tabular}{|l|c|c|c|c|}
\hline \multicolumn{1}{|c|}{ Components } & Australia & Qatar & US & unit \\
\hline Fuel consumption (laden) & 141.11 & 141.11 & 141.11 & MT /day \\
\hline & 533.90 & $1,295.04$ & $3,984.26$ & $\mathrm{MT}$ \\
\hline Fuel consumption (ballast) & 138.99 & 138.99 & 138.99 & $\mathrm{MT} /$ day \\
\hline & 525.88 & $1,275.59$ & $3,924.40$ & $\mathrm{MT}$ \\
\hline In Port (cargo operation) & 50.00 & 50.00 & 50.00 & $\mathrm{MT}$ \\
\hline Total fuel consumption & $1,109.78$ & $2,620.63$ & $7,958.66$ & $\mathrm{MT} /$ voyage \\
\hline Fuel price & 581.42 & 581.42 & 581.42 & USD / tonne \\
\hline Fuel oil cost & $\mathbf{6 4 5 , 2 4 8 . 6 1}$ & $\mathbf{1 , 4 9 4 , 6 1 5 . 8 1}$ & $\mathbf{4 , 5 9 8 , 2 5 0 . 4 4}$ & USD / voyage \\
\hline & $\mathbf{0 . 2 4}$ & $\mathbf{0 . 5 5}$ & $\mathbf{1 . 6 9}$ & USD / MMBtu \\
\hline
\end{tabular}

For the second scenario, the total energy required by the LNG carrier is met by the boil-off gas generated in ladden and ballast condition. The total energy needed from three different countries is shown in Table II. Based on the calculation of boil-off gas generated in Table III, the total energy required from Australia, Qatar, and the US can be covered by the BOG only. In other words, the pure-gas burning system is feasible because the vessel does not need fuel oil to support the BOG in the burning system. Although there is no component of fuel oil cost, the total energy of LNG transferred to storage in the port destination will decrease.

Table 2: The Total Energy Required for LNG Carrier

\begin{tabular}{|c|c|c|c|c|}
\hline Components & Australia & Qatar & US & unit \\
\hline $\begin{array}{c}\text { Total fuel } \\
\text { consumption }\end{array}$ & $1,109.78$ & $2,620.63$ & $7,958.66$ & $\mathrm{MT} /$ voyage \\
\hline & $43,281,442$ & $102,204,578$ & $310,387,562$ & $\mathrm{MJ} /$ voyage \\
\hline & $\mathbf{4 1 , 0 2 3}$ & $\mathbf{9 6 , 8 7 1}$ & $\mathbf{2 9 4 , 1 9 1}$ & $\mathrm{MMBTu} /$ voyage \\
\hline
\end{tabular}

Table 3: Boil-Off Gas Generated

\begin{tabular}{|c|c|c|c|c|}
\hline Components & Australia & Qatar & US & unit \\
\hline Boil off rate (ladden) & $0.15 \%$ & $0.15 \%$ & $0.15 \%$ & $\mathrm{~m} 3 /$ day \\
\hline & 1,419 & 3,442 & 10,588 & $\mathrm{~m} 3 /$ voyage \\
\hline & 30,931 & 75,026 & 230,822 & $\mathrm{MMBTu} /$ voyage \\
\hline Boil off rate (ballast) & $0.06 \%$ & $0.06 \%$ & $0.06 \%$ & $\mathrm{~m} 3 /$ day \\
\hline & 568 & 1,377 & 4,235 & $\mathrm{~m} 3 /$ voyage \\
\hline & 12,372 & 30,011 & 92,329 & $\mathrm{MMBtu} /$ voyage \\
\hline & $\mathbf{1 , 9 8 6}$ & $\mathbf{4 , 8 1 8}$ & $\mathbf{1 4 , 8 2 3}$ & $\mathbf{m 3} /$ voyage \\
\hline Total & $\mathbf{4 3 , 3 0 3}$ & $\mathbf{1 0 5 , 0 3 7}$ & $\mathbf{3 2 3 , 1 5 1}$ & MMBtu / voyage \\
\hline
\end{tabular}




\subsection{Shipping Cost}

The cost to ship one MMBtu of liquefied natural gas from three different countries is given in Table IV. Shipping costs range from 0.43 to 3.16 USD / MMBtu depending on the LNG sources. The shipping cost from the US is the highest one with 31.16 USD / MMBtu because of the longer distance than Australia and Qatar. On the other hand, shipping cost from Australia and Qatar are 0.43 and 1.03 USD / MMBtu respectively. The total shipping cost incurred is still likely to increase because the regasification cost component has not been included in the calculation model.

Table 4: Shipping Cost Calculation

\begin{tabular}{|l|c|c|c|c|}
\hline \multicolumn{1}{|c|}{ Cost Components } & Australia & Qatar & US & unit \\
\hline Port and passage fees & 0.04 & 0.11 & 0.33 & USD / MMBtu \\
\hline LNG carrier hire cost & 0.15 & 0.37 & 1.14 & USD / MMBtu \\
\hline Fuel oil cost & 0.24 & 0.55 & 1.69 & USD / MMBtu \\
\hline Total shipping cost & $\mathbf{0 . 4 3}$ & $\mathbf{1 . 0 3}$ & $\mathbf{3 . 1 6}$ & USD / MMBtu \\
\hline
\end{tabular}

Fuel oil and LNG carrier hire cost have a higher impact on the total shipping cost compared to port and passage fees. The fuel oil and LNG carrier hire cost themselves are related to the total sailing days. If the sailing duration from a country is higher than another country, the cost of vessel hire will be higher because in the case given, the vessel is chartered based on time charter.

\section{Conclusions}

Using the pure HFO burning system, the shipping costs from Australia, which costs 0.43 USD / MMBtu, has the lowest rate among three countries analysed for an average transport distance of 3,200 $\mathrm{nm}$. For Qatar and the US, the shipping costs are 1.03 and 3.16 USD / MMBtu for an average transport distance of 7,762 nm and 23,880 nm, respectively. From the analysis, it was found that the shipping costs are most sensitive to the sailing distances. The pure-gas burning propulsion system is also feasible to be used because the vessel does not need fuel oil to support the BOG in the burning system. The boil-off gas generated is more than enough to meet the energy required of the vessel to sail from the exporter countries to Indonesia. The cost-benefit of using boil-off gas produced rather than oil fuel as a primary fuel should be studied further to give more comprehensive analysis.

\section{References}

[1] Ministry of Energy and Mineral Resources (2017). Oil and Gas Statistics 2017.

[2] Ministry of Energy and Mineral Resources. (2014). Roadmap of Indonesian Natural Gas Policy 2014-2030.

[3] Suslick, S. B., Schiozer, D., \& Rodriguez, M. R. (2009). Uncertainty and Risk Analysis in Petroleum Exploration and Production

[4] Abdul Rashid, I. M., Putrohari, R. D., Kasyanto, A., \& Heri, S. (2007). Psc Term and Condition and Its Implementation in South East Asia Region. Proceedings, Indonesian Petroleum Association Thirty-First Annual Convention and Exhibition, (May), 1-18.

[5] Fiscal Affairs Department. (2012). Fiscal Regimes for Extractive Industries: Design and Implementation. Washington D.C.

[6] Johnston, D. (1994). International Petroleum Fiscal Systems and Production Sharing Contracts (1st Editio). Tulsa: PennWell Publishing Company.

[7] Pudja, I. G. N. W., Dwiantoro, D., \& Simarmata, M. R. (2016). Virtual Pipeline to Support Natural Gas Infrastructures Development in Eastern Indonesia Region, (October), 1-16.

[8] Research and Development Center for Marine and Coastal Resources. (2016). Map of Indonesia.

[9] Griffin, P. (2012). The Law and Bussiness of LNG, Second Edition.

[10] Mokhatab, S., Mak, J. Y., Valappil, J. V, \& Wood, D. A. (2014). Handbook of Lique fi ed Natural Gas. https://doi.org/10.1016/B978-0-12404585-9.01001-1

[11] Thomas, S., \& Dawe, R. A. (2003). Review of ways to transport natural gas energy from countries which do not need the gas for domestic use. Energy, 28(14), 1461-1477. https://doi.org/10.1016/S0360-5442(03)00124-5 
[12] Minister of Energy and Mineral Resources. (2017). Minister Regulation No. 11/2017

[13] Jiang-Bo Geng, Qiang Ji, Ying Fan, Faheemullah Shaikh, (2017), Optimal LNG importation portfolio considering multiple risk factors, Journal of Cleaner Production, Volume 151, 2017, Pages 452-464, ISSN 0959-6526,

[14] Sepideh Jafarzadeh, Nicola Paltrinieri, Ingrid Bouwer Utne, Harald Ellingsen, (2017), LNG-fuelled fishing vessels: A systems engineering approach, Transportation Research Part D: Transport and Environment, Volume 50, 2017, Pages 202-222, ISSN 1361-9209,

[15]Jingzheng Ren, Marie Lützen, (2017), Selection of sustainable alternative energy source for shipping: Multi-criteria decision making under incomplete information, Renewable and Sustainable Energy Reviews, Volume 74, 2017, Pages 1003-1019, ISSN 1364-0321,

[16] O. Schinas, M. Butler, (2016), Feasibility and commercial considerations of LNG-fueled ships, Ocean Engineering, Volume 122, 2016, Pages 8496, ISSN 0029-8018,

[17] Israt Mustary, Harun Chowdhury, Bavin Loganathan, Firoz Alam, (2017), Development of a Computational Model for Optimal Sourcing of LNG Energy Procedia, Volume 110, 2017, Pages 597-603, ISSN 1876-6102,

[18]Patel, B. (2005) 'Gas Monetisation: A Techno-Economic Comparison of Gas-To-Liquid and LNG', 7th World Congress of Chemical Engineering, Glasgow, pp. 1-11.

[19]Zhihua Chen, Haizhong An, Xiangyun Gao, Huajiao Li, Xiaoqing Hao, (2016), Competition pattern of the global liquefied natural gas (LNG) trade by network analysis, Journal of Natural Gas Science and Engineering, Volume 33, 2016, Pages 769-776, ISSN 1875-5100,

[20]Alexander Q. Gilbert, Benjamin K. Sovacool, (2017), US liquefied natural gas (LNG) exports: Boom or bust for the global climate?, Energy, Volume 141, 2017, Pages 1671-1680, ISSN 0360-5442

[21] Pun-Lee Lam, (2000), The growth of Japan's LNG industry: Lessons for China and Hong Kong, Energy Policy, Volume 28, Issue 5, 2000, Pages 327-333, ISSN 0301-4215

[22] Kenneth B. Medlock, Amy Myers Jaffe, Meghan O'Sullivan, (2014), The global gas market, LNG exports and the shifting US geopolitical presence, Energy Strategy Reviews, Volume 5, 2014, Pages 14-25, ISSN 2211-467X,

[23] Vlado Vivoda, (2014), Natural gas in Asia: Trade, markets and regional institutions, Energy Policy, Volume 74, 2014, Pages 80-90, ISSN 03014215 ,

[24]Alice Bittante, Raine Jokinen, Frank Pettersson, Henrik Saxén, (2015) Optimization of LNG Supply Chain, Editor(s): Krist V. Gernaey, Jakob K. Huusom, Rafiqul Gani, Computer Aided Chemical Engineering, Elsevier, Volume 37, 2015, Pages 779-784, ISSN 1570-7946, ISBN 9780444634290

[25] Jensen, J. (2003). 'The LNG Revolution', Energy Journal of the International Association for Energy Economics, 24(2)

[26] Baris Burak Kanbur, Liming Xiang, Swapnil Dubey, Fook Hoong Choo, Fei Duan, (2017), Cold utilization systems of LNG: A review, Renewable and Sustainable Energy Reviews, Volume 79, 2017, Pages 1171-1188, ISSN 1364-0321 